\title{
Copper and Compost Induced Sweet Potatoes Production in Sandy Soil
}

\author{
Syed Ahmad Naqib, Wan Nur Khairunisha, Mohd Khairi, Mohd Nozulaidi \\ Faculty of Bioresources and Food Industry, Universiti Sultan Zainul Abidin, (UNISZA), Tembila campus, 22200 \\ Besut, Terengganu, Malaysia.
}

\begin{abstract}
Compostincreases nutrients holding capacity in sandy soil through increasing soil health. To examine the effects of compost-and copper $(\mathrm{Cu})$-inducedsweet potato production, different plants parameters of sweet potato were measured. A foliar application of diverse concentrations of $\mathrm{Cu}(0.0,0.2,1.5$ and $3.0 \mathrm{ppm})$ with or without compost were arranged according to the completely randomize design with five replications. Copper application enhanced leaf area, chlorophyll (Chl) content, relative water content (RWC), photosynthesis rate, tuber weight of sweet potato. Copper application increased above parameters regardless of $\mathrm{Cu}$ application. Copper concentration at 1.5ppm showed improved results compared to the control and other concentrations of $\mathrm{Cu}$. These results indicate that compost and Cumight increase the production of sweet potato in low fertile soil through improving physiological functions of the plants.
\end{abstract}

Keywords: chlorophyll contents, leaf area, relative water content, photosynthesis, tuber

\section{Introduction}

Sweet potato (Ipomoe batatas L.) is the major crop grown in a tropic area and is a source of protein, vitamin A and vitamin E, in pharmaceutical, paper and textile industry (Truong, 1989). The production of the sweet potato decreased due to the poor soil quality such as degradation of the land, mineralization of organic matter, crop removal and high rainfall (IITA, 1995).The application of the manure and fertilizers significantly improve the growth and yield of sweet potato (Salawu and Mukhtar, 2008).Compost is a good source of organic fertilizer for different essential plantnutrients (Franklin, 1998) to be added in soil and sustain crop yields (Chelah et al., 2011).Previous results confirms that organic matter manage low fertile soil for sustainable crop production (Nyamangara et. al., 2003) through improving soil health (Laird et al., 2001; Chelah et al., 2011). Compost on the other hand drops soil-borne diseases,soil pollution and improvenutrients holding capacity(Nyamangara et al., 2003).

Copper controls photosynthetic rate and electron transport chains in the respiratory system and cell wall metabolism (Yruela 2009), signalling mechanism, iron mobilization and phosphorylation in the cells of plants (Yruela 2005). Higher concentration of $\mathrm{Cu}$ inhibits plant growth and proteins activity (Morelli and Scarano 2004) which optimize concentrations increase plant growth and development (Vermaet al. 2011; Syuhada et al., 2014). Lower and higher copper lowers photosynthesis and respiration rate as well as young leaves and defective of reproductive organ (Yruela, 2005; Syuhada and Jahan, 2016).

The earlier report showed that compost improved sandy soil health to sustainriceproduction (Chelah et al., 2011).To date, there is no information on the effects of compost- and $\mathrm{Cu}$-inducedthe production of sweet potato in sandy soil. Therefore, the present study concentrated to justify the effectiveness of compost and $\mathrm{Cu}$ on sustains sweet potato production. We showed that compost increased Cu-induced sweet potato productionby way of enhancing physiological functions of the sweet potato plants.

\section{Experimental Set up}

\section{Materials and Methods}

The sweet potato(Ipomea batatas L.)variety of VitAto was used for this experiment.Four $\mathrm{Cu}$ concentrations $(0,0.2,1.5$ and $3.0 \mathrm{ppm})$ were applied to the sweet potato plantswith or without compostcondition. Treatments were arranged according to thecompletely randomize design with five replicates.Compost was mixed with the sandy soil and stabilizes for two weeks before planting of vines. The prepared land was constructed into beds where vines were planted in a distance of $30 \mathrm{~cm}$ between two veins. Inorganic fertilizers such as nitrogen $(100 \mathrm{~kg})$ phosphorous $(90 \mathrm{~kg})$ and potassium $(200 \mathrm{~kg})$ per ha were applied according to the guidelines provided by the Department of Agriculture, Malaysia. During tuber development, a $300 \mathrm{~kg}$ of NPK blue (12:12:17 + TE) was appliedto boost tuber production.

\section{Determine of Parameters}

A LP-80 leaf area meter was used to measure the leaf area of sweet plants (Jahan et al., 2014). Relative water content of leaves was estimated as per previous studies (Jahan et al., 2013, Khairi et al., 2015a). Detached 
leaves were measured for a fresh weight $(\mathrm{FW})$ then incubated in distilled water for 24 hours. The leaves were dabbed dry using soft tissue paper then measure the turgid weight (TW) followed by the dry weight after leaves were oven driedin an oven at $65^{\circ} \mathrm{C}$ for 24 hours. The following formula of RWC $(\%)=[(\mathrm{FW}-\mathrm{DW}) /(\mathrm{TW}-\mathrm{DW})]$ $\mathrm{x} 100$ was used to calculate relative water content (RWC) of leaves sweet potato. Moisture contentsof tuber weremeasuredas per the previous method (Abdulkadir et al., 2016). The following formula was used to calculate the moisture contents of tuber.

Percentage Moisture $=\left\{\left(\mathrm{W}_{2}-\mathrm{W}_{3}\right) \times 100\right\} \times\left(\mathrm{W}_{2}-\mathrm{W}_{1}\right)$

Where $\mathrm{W}_{1}=$ weight of empty crucible $(\mathrm{g}) ; \mathrm{W}_{2}=$ weight of crucible + sample prior to drying $(\mathrm{g})$ and $\mathrm{W}_{3}=$ weight of crucible + sample after drying $(\mathrm{g})$.

A portable SPAD chlorophyll meter was used to determine chlorophyll (Chl) contentof leaves as per previous study (Jahan et al., 2014).A portable gas exchange fluorescence system (CI-340 Handheld Photosynthesis System) was used to measure the net photosynthesis rate (pn; $\mu \mathrm{mol} / \mathrm{m} 2 / \mathrm{s}$ )of plants (Khairi et al., 2015b; Munirah et al., 2015a). Measurements were taken between 11:00 am and 1:00 pm to avoid the wetness condition on leaves with five replicates. Yields as tuber weight were estimated using a weighting balance. Proper agronomic practices were taken as per previous studies (Sarwar et al., 2004, Sarwar and Khanif, 2005a). Data were analysed by the ANOVA procedure and differences of mean among treatments wereanalysed by the Minitab version-16 software. Differences at $P$ value $<0.05$ was considered significant.

\section{Result \\ Effects of compost and $\mathrm{Cu}$ on leaf area of sweet potato plants}

Leaf area of sweet potatoes gradually increased with increasing $\mathrm{Cu}$ concentration until at the $1.5 \mathrm{ppm}$ concentration (Fig. 1; closed bars). But $\mathrm{Cu}$ at $3.00 \mathrm{ppm}$ showed a similar of effect on leaf area as compared to the $1.5 \mathrm{ppm}$ of $\mathrm{Cu}$ concentration. Figure 1 also shows that leaf area of the compost-treated sweet potato plants increased significantly compared to the compost-untreated plants (Fig. 1; open bars). In addition, compostinduced leaf area of sweet potato plants was similar regardless of $\mathrm{Cu}$ treatment. Similar results were observed when compost and $\mathrm{Cu}$ were applied together. This result confirmed that compost application increased leaf area regardless of $\mathrm{Cu}$ application.

\section{Effects of compost and $\mathrm{Cu}$ on chlorophyll contents of leaves}

Chlorophyll content is related to the light antenna complexes in photosystem II (Jahan et al., 2016) and the net photosynthesis rate in leaves of plants (Munirah et al., 2015b; Syuhada et al., 2014). Cu application gradually induced $\mathrm{Chl}$ content in leaves of sweet potato plants with increasing $\mathrm{Cu}$ concentration (Fig.2; open Square). In addition, $\mathrm{Cu}$ application significantly increased $\mathrm{Chl}$ content compared to the control treatment. This result was consistent with the previous study (Syuhadah and Jahan, 2016). Compost-treated Chl contents increased significantly regardless of $\mathrm{Cu}$ treatment but a similar trend of $\mathrm{Chl}$ content was observed in both $\mathrm{Cu}$ and compost conditions. In addition, under 1.5 and $3 \mathrm{ppmCu}$ conditions, compost did not show any effect on $\mathrm{Chl}$ content. These results indicate that compost might increase $\mathrm{Chl}$ content in leaves throughmodulatingthe function of physiological activity in plants.

\section{Effects of compost and $\mathrm{Cu}$ on relative water content of leaves and moisture content in tuber}

Figure 3 demonstrates compost- and $\mathrm{Cu}$-induced RWC of leaves and moisture content of tuber of sweet potato plants. Copper increased RWC of leaves with increasing $\mathrm{Cu}$ concentration. Likewise, compost increased RWC of leaves of $\mathrm{Cu}$-untreated and -treated sweet potato plants. But $\mathrm{Cu}$-treated plants accumulated higher RWC in leaves than that of $\mathrm{Cu}$-untreated plants in the presence of compost (Fig. 3, bar graphs). Moisture contents in tuber, on the other hand, under different treatments were similar to the RWC of leaves. These results indicate that compost and $\mathrm{Cu}$ increased water content in leaves and tuber but compost enhanced $\mathrm{Cu}$-induced water content in leaves and tuber (Fig. 3, line graphs).

\section{Effects of compost and $\mathrm{Cu}$ on photosynthesis rate}

Figure 4 displays compost and $\mathrm{Cu}$ induced net photosynthesis rate of leaves of sweet potato plants. Low concentration of $\mathrm{Cu}(0.2 \mathrm{ppm})$ treatment increased net $\mathrm{Pn}$ rate of leaves compared to the control and higher $\mathrm{Cu}$ concentration (3 ppm of $\mathrm{Cu}$; Fig. 4; closed bars). This result suggests that $\mathrm{Pn}$ rate might show adosedependency to $\mathrm{Cu}$ concentration. In addition, compost application not ably enriched $\mathrm{Pn}$ rate of leaves of $\mathrm{Cu}-$ untreated plants as well as in Cu-treated plants (Fig. 4a; open bars). This result indicates that compost application in sandy soil might improves oil health, therefore Pn rate increased to induce production.

\section{Effects of compost applicationonCu-induced weight of tuber}

Whether composting affects $\mathrm{Cu}$-induced sweet potato production, we measuredthe weight of tuber after harvested of the tubers. Figure 5a shows that 1.5 concentration of $\mathrm{Cu}$ application significantly increasedweight 
of tuber compared to the control but similar to $3 \mathrm{ppm} \mathrm{Cu}$ application. In addition, compost application significantly inducedweight of tuber regardless ofCu treated plants (Fig. 5; under $0 \mathrm{ppm}$ of Mn). These results indicate that compost-induced production oftuber was not affected bythe different concentrationsof $\mathrm{Cu}$ (Fig. 5).Weight of tuber was consistent with physiological functions of the plants. This result suggests that compost andCu increased corn production in low fertile soil.

\section{Discussion}

Sandy soil has high percentage of sand which lowersthe water and nutrients holding capacity in soil to inducea detrimental effectfor most field crops.On the other hand, compost improves structure of sandy soilstomaintain nutrients availability from where plants absorb nutrients.Good compost contains essential plant nutrients at different concentrations to be used by the plant as well as improve plantgrowth (Rosen \& Bierman, 2005) and soil health (Chelah et al., 2011). Soil water condition affects $\mathrm{Cu}$ in soil solution (Sarwar and Khanif, 2005b).This studyshowed that compostand $\mathrm{Cu}$ both significantly increased the area of leaf of sweet potato plants (Fig. 1). This result indicates that application of $\mathrm{Cu}$ and compost improved physiological and soil function, respectively. In this connection, the Chl content increased in leaves of $\mathrm{Cu}$-treated sweet potato plants (Fig. 2). Increasing $\mathrm{Chl}$ content in leaves indicates of higher photosynthesis production in plants, which might increase physiological functions in plants (Jahan et al., 2014, 2016).Chlorophyll content is associated with the GSH accumulation in plants and light-dependent physiological functions in the plants (Nozulaidi et al., 2015, Inani et al., 2015; Munirah et al., 2015b). These results indicate that light related parameters are regulated by the Chl function in leaves to maintain the growth of the plants. Low fertile soil affects $\mathrm{CO}_{2}$ assimilation in leaves that shrink Chl contents in leaves to regulatethe productivity of crops (Sheela and Alexander, 1996; Chelah et al., 2011). Above results showed consistent with this study that accumulation of lower level of Chl content in plants under sandy soil (Fig. 2). In addition compost application increased $\mathrm{Chl}$ content was irrespective to the $\mathrm{Cu}$ application (Fig. 2). This result indicates that the health of sandy soil might be improved due to the application of compost at least at the character ofwater holding capacity of soil. Increment of $\mathrm{Chl}$ content in leaves of compost-treated plants indicates of higher GSH accumulation that might improve physiological functions of plants (Jahan et al., 2011 and 2014).

Water levels (Khairi et al., 2015b; 2016), salinity (Nozulaidi et al., 2015), nutrients andsandy soil(Syuhada and Jahan, 2016; Inani et al., 2015; Munirah et al., 2015a)shake RWC of leaves of plants. Fig 3 demonstrates that application of $\mathrm{Cu}$ and compost enhanced RWC in leaves and moisture content of sweet potato. This is the indication of improvingthe health of sandy soil with the coordinationof the application of compost in sandy soil. Leaf-low-water causes considerable fluctuations of the transformation of the light energy in photosystems (Kameli \& Losel, 1993) which might enhance physiological functions of the plants. In this relation, the photosynthesis rate in leaves of plants increased in the presence of compost (Fig. 4) and consistent with previous study (Berkowitz, 1998) might improvethe transpiration rate (Mukhopadhyay et al. 2013) and cell membrane integrity (Richardson et al. 1993). The application of compost increases microbial activity,nutrients concentration to sustainyield of production (Tejada and Gonzalez, 2003). Finally, $\mathrm{Cu}$ and compost applications increase the production of weight of tuber and $1.5 \mathrm{ppm}$ of $\mathrm{Cu}$ with compost show better result.In conclusion, compost might improve the soil health and $\mathrm{Cu}$ increased physiological functionsthat together sustain yield of sweet potato plants in sandy soil.

\section{Acknowledgement}

This work was supported by the faculty of Bioresources and Food Industry, University Sultan Zainal Abidin, Malaysia.

\section{References}

[1] Abdulkadir AR, Zawawi DD, Jahan MS (2016) Proximate and phytochemical screening of different parts of Moringa oleifera. Russian Agricultural Sciences 42:24-26

[2] Berkowitz GA (1998) Water and salt stress.-In: Raghavendra, A.S. (ed.): Photosynthesis. A comprehensive treatise.Cambridge University Press, Cambridge. PP. 226-237.

[3] Chelah MKB, Nozulaidi MN, Musliania MI, Khanif YM, Jahan MS (2011) Composting increases BRIS soil health and sustains rice production on BRIS Soil. Science Asia 37:291-295.

[4] Franklin (1998) "Characterization of municipal solid waste": 1997 Update (prepared for the USEPA), Prairie Village, Kansas

[5] IITA (1995) Plant Health Management Division.Annual Report, p. 43

[6] Inani N, Nozulaidi M, Khairi M, Abdulkadir AB, Jahan MS (2015) Glutathione functions on physiological characters of corn plants to enhance Mn-induced corn production. Pertanika Journal Tropical Agriculture Sciences 38:509-581.

[7] Jahan MS, Khanif YM, Sinniah UR (2013b) Effects of low water input on rice yield: Fe and Mn bioavailability in soil. Pertanika Journal of Tropical Agricultural Science 36:27-34.

[8] Jahan MS, Nakamura Y, Murata Y (2011) Histochemical quantification of GSH contents in guard cells of Arabidopsis thaliana. Scienceasia 37: 281-284.

[9] Jahan MS, Nozulaidi M, Khairi M, Mat N (2016) Light-harvesting complexes in photosystem II regulate glutathione-induced sensitivity of Arabidopsis guard cells to abscisic acid. Journal Plant Physiology 195:1-8. 
[10] Jahan MS, Nozulaidi M, Khandaker MM, Afifah A, Husna N (2014) Control of plant growth and water loss by a lack of lightharvesting complexes in photosystem-II in Arabidopsis thaliana ch1-1 mutant. Acta Physiologia Plantarum 36:1627-1635.

[11] Kameli A, Losel DM (1993) Carbohydrates and water status in wheat plants under water stress.New Phytology 125:609-614.

[12] Khairi M, Nozulaidi M, Afifah A, Jahan MS (2015a) Effect of various water regimes on rice production in lowland irrigation. Australian Journal of Crop Science 9:153-159.

[13] Khairi M, Nozulaidi M, Jahan MS (2015b) Effects of different water levels on physiology and yield of salinity rice variety. Australian Journal of Basic and Applied Sciences 9(2):339-345.

[14] Khairi M, Nozulaidi M, Jahan MS (2016) Effects of flooding and alternate wetting and drying on the yield performance of upland rice. The PertanikaJournal of Tropical Agricultural Science 39 (3):299-309.

[15] Laird DA, Martens DA, Kingery WL (2001) Nature of clay-humic complexes in an agricultural soil: i. chemical, biological, and spectroscopic analyses. Soil Science Society of American Journal 65:1413-1418.

[16] Morelli E, Scarano G (2004) Copper-induced changes of non-protein thiols and antioxidant enzymes in the marine microalga Phaeodactylum tricornutum. Plant Science 167:289-296.

[17] Mukhopadhyay MS, Das A, Subba P, Bantawa P, Sarkar B, Ghosh P, Mondal TK (2013) Structural, physiological, and biochemical profiling of tea plants under zinc stress. Bioligia Plantarum 57(3):474-480.

[18] Munirah N, Jahan MS, Nashriyah M (2015b) N-acetylcysteine and Zn regulate corn yield. Science Asia 41:246-250.

[19] Munirah N, Khairi M, Nozulaidi M, Jahan MS (2015a) The effects of zinc application on physiology and production of corn plants. Australian journal of basic and applied sciences 9:362-367.

[20] Nozulaidi M, Khairi M, Jahan MS (2015) Effects of different salinity levels on rice production. Australian Journal of Basic and Applied Sciences 9(5):524-530.

[21] Richardson MD, Hoveland CS, Bacon CW (1993) Photosynthesis and stomatal conductance of symbiotic and nonsymbiotic tall fescue. Crop Science 33:145-149.

[22] Rosen CJ, Bierman PM (2005) Soils and composting.http://www.extension.umn.edu/ garden/yard-garden/soils/. Accessed on 08 June 2016.

[23] Salawu IS, Mukhtar AA (2008) Reducing the dimension of growth and yield characters of sweet potato (Ipomoea batatas L.) varieties as affected by varying rates in organic and inorganic fertilizer. Asian Journal of Agricultural Research 2(1): 41-44.

[24] Sarwar MJ, Khanif YM (2005a) Techniques of water saving in rice production in Malaysia.Asian Journal of Plant Sciences 4:8384.

[25] Sarwar MJ, Khanif YM (2005b) The effect of different water levels on rice yield and $\mathrm{Cu}$ and $\mathrm{Zn}$ concentration. Journal of Agronomy 4:116-121.

[26] Sarwar MJ, Khanif YM, Syed Omar SR, Sinniah UR (2004) The effect of different water regimes on yield and bioavailability of Phosphorus in rice production in Malaysia. The Malaysian Journal of Soil Science8:53-62.

[27] Sheela KR, Alexander VT (1996) Physiological response of rice varieties as influenced by soil moisture and seed hardening.Indian Journal of Plant Physiology 38: 269-271.

[28] Syuhada N, Jahan MJ (2016) Glutathione functions on physiological characters to increase copper-induced corn production. Russian Agricultural Science 42:5-10.

[29] Syuhada N, Jahan MS, Nashriyah M, Khairi M, Nozulaidi M, Razali MHB (2014) Application of copper increased corn yield through enhancing physiological functions. Australian Journal of Basic and Applied Sciences 8:282-286.

[30] Tejada M, Gonzalez J (2003) Effects of the application of a compost originating from crushed cotton gin residues on wheat yield under dry land conditions. The European Journal of Agronomy 19: 357-368.

[31] Truong, VD (1989) New developments in processing sweet potato for food.Pages 213-226 in Sweet potato research and development for small farmers, edited by K.T. Mackay and R.T. Sanico.SEARCA, Los Banos Philippines.

[32] Verma JP, Singh V, Yadav J (2011) Effect of copper sulphate on seed germination, plant growth and peroxidase activity of Mung bean (Vignaradiate)," International Journal of Botany 7:200-204.

[33] Yruela I (2005) Copper in plants. Brazilian Journal Plant Physiology 17:145-156.

[34] Yruela I (2009) Copper in plants: acquisition, transport and interactions. Functional Plant Biology36:409-430.

\section{Figure Legend}

Fig. 1 Effects of different concentration of $\mathrm{Cu}$ onarea of leaf of compost (open bars)-treated and compost (closed bars)-untreated sweet potato plants. Error bars represents standard deviation with 5 replicates.

Fig. 2Effects of different concentration of Cuon chlorophyll content of leaves of compost (open square)-treated and compost (open triangle)-untreated sweet potato plants. Error bars represents standard deviation with 5 replicates.

Fig. 3Effects of different concentration of $\mathrm{Cu}$ and composton relative water content in leaves (bad graphs) and moisture content of tuber (line graphs) of sweet potato plants. Error bars indicate standard deviation with 5 replicates.

Fig. 4Effects of different concentration of $\mathrm{Cu}$ and composton photosynthesis rate of leaves of sweet potato plants. Error bars indicate standard deviation with 5 replicates.

Fig. 5Effects of different concentration of $\mathrm{Cu}$ and composton weight of tuber of sweet potato plants. Error bars indicate standard deviation with 5 replicates. 


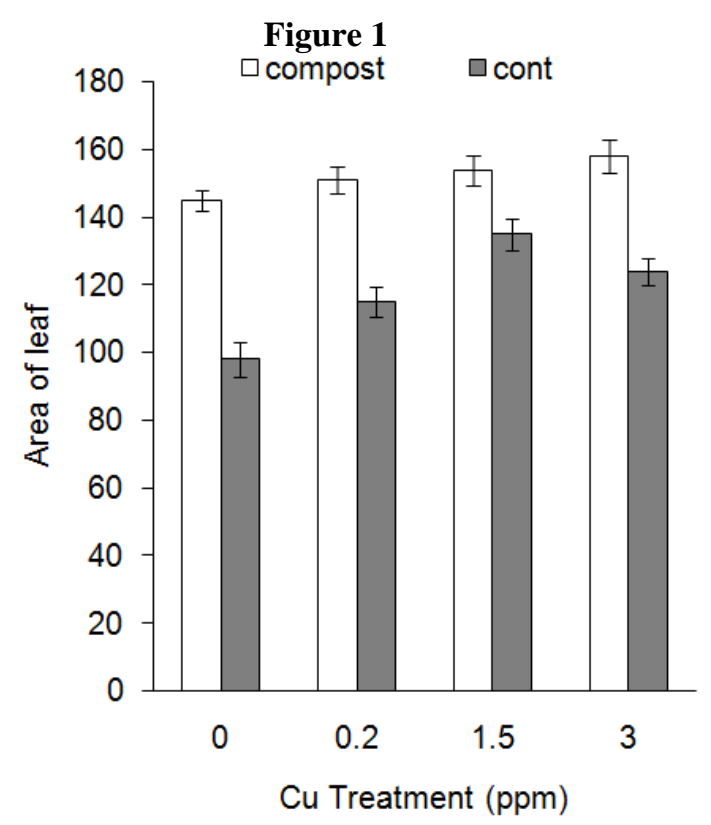

Figure 2

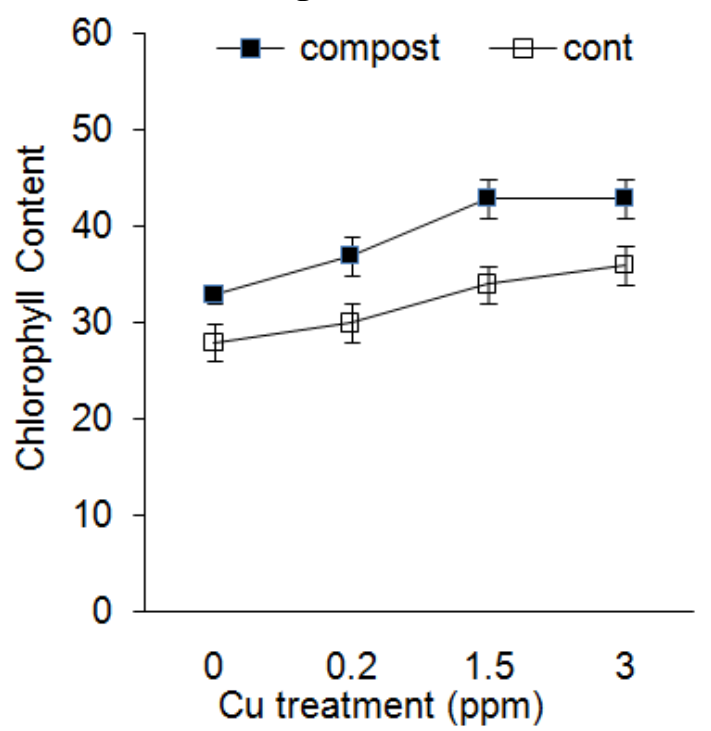

Figure 3

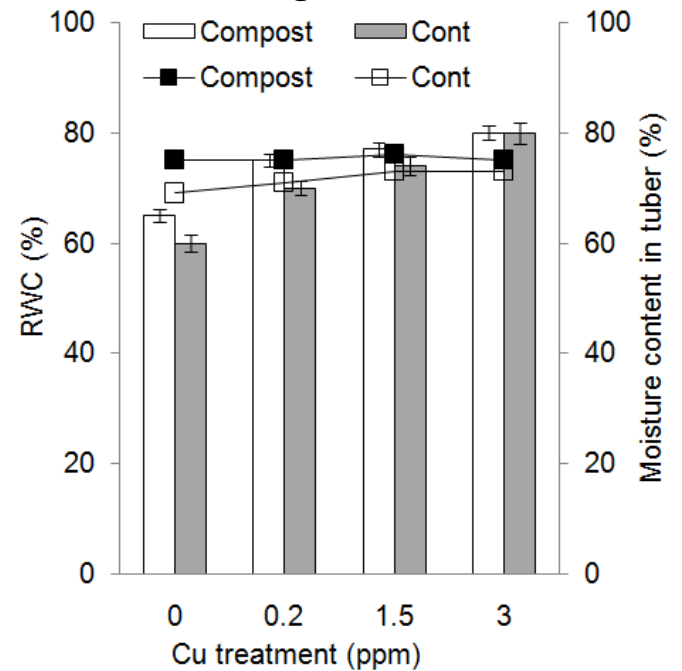



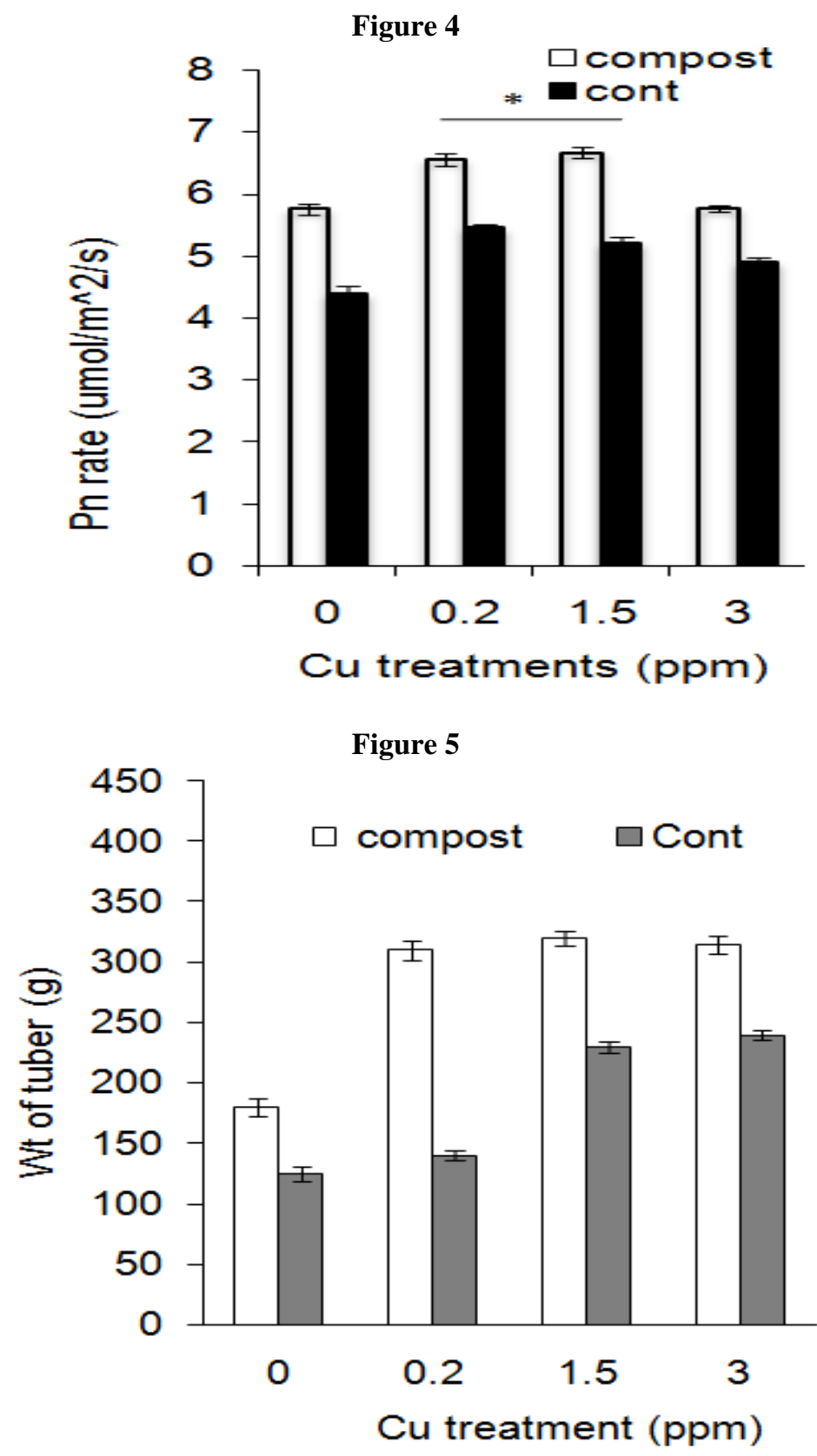